\title{
Increased ROS Generation: Implication in Antibacterial Activity of Evolvulus nummularius against Multidrug Resistant Gram Negative Bacterial Strains
}

\author{
Susmita Saha ${ }^{1}$, Anindya Das ${ }^{1}$, Angkita Debnath ${ }^{1}$, Shipa Begam ${ }^{1}$, Subrata Sen ${ }^{1}$, \\ Swapan Majumdar ${ }^{2}$ and Samir Kumar Sil ${ }^{1 *}$
}

\author{
${ }^{1}$ Molecular Genetics and Cell Physiology Lab., Department of Human Physiology, Tripura \\ University, Suryamaninagar, West Tripura-799022, India. \\ ${ }^{2}$ Department of Chemistry, Tripura University, Suryamaninagar, West Tripura-799022, India
}

*Corresponding author

\author{
A B S T R A C T
}

\begin{tabular}{|l|}
\hline K e y w o r d s \\
$\begin{array}{l}\text { Evolvulus } \\
\text { nummularius, Gram } \\
\text { negative bacteria, } \\
\text { MDR strains, } \\
\text { Growth curve, ROS. }\end{array}$ \\
\hline Article Info \\
\hline $\begin{array}{l}\text { Accepted: } \\
12 \text { December } 2016 \\
\text { Available Online: } \\
\text { 10 January } 2017\end{array}$ \\
\hline
\end{tabular}

Evolvulus nummularius, is ethnomedicinally used as a medicine for hysteria, to cure burns, cuts, wounds and scropion stings. This plant has antihelminthic activity, wound healing activity, poor sedative and anticonvulsant properties. In this study, the antibacterial activity of crude methanol extract of $E$. nummularius was studied against three gram negative multidrug resistant strains $E$. aerogenes, $P$. aeruginosa and $K$. pneumoniae. This plant extract showed both bacteriostatic and bactericidal activity against all these bacterial strains. The extract was most active against E. aerogenes. In growth analysis study, it was obtained that, after treatment with $\mathrm{IC}_{50}$ dose for each bacterial strains, the lag phase become extended compared to untreated bacterial cells. To understand the mechanism of action of Evolvulus nummularius the reactive oxygen species (ROS) was estimated and result showed that, reactive oxygen species were increased $(\sim 35-60 \%)$ in presence of $\mathrm{IC}_{50}$ dose of Evolvulus nummularius.

\section{Introduction}

The frequency of infections by pathogenic microorganisms has increased worldwide and is an important factor of morbidity and mortality in developing countries (Al-Bari et al., 2007).

As the number of multidrug resistant bacterial strains are increasing day-by-day, so, the identification of new infectionfighting strategies is necessary (Zy et al., 2005, Rojas et al., 2006). Therefore, the demand for plant based therapeutics in both developed and developing countries is increasing.

Tripura, small state of the north-eastern region of India is rich in biodiversity with vast resource of medicinal plants (Deb, 1983; Das et al., 2009; Roy et al., 2010). Evolvulus nummularius has antihelminthic activity (Dash et al., 2003), wound healing activity (Saini et al., 2007), poor sedative and anticonvulsant properties (Chitralekha et al., 1964). Phytochemical analysis of aerial parts 
of $E$. nummularius revealed that, it had three new compounds, 1-3 along with $\beta$-sitosterol and its glucoside, stigmasterol, $d$-mannitol, ursolic acid and oleanolic acid (Dinda et al., 2007).

Aerobic bacteria use molecular oxygen $\left(\mathrm{O}_{2}\right)$ for respiration or oxidation of nutrients to obtain energy. During the whole life cycle bacterial species are remains in continuous contact with reactive oxygen species (ROS) generated by endogenously, as a product of aerobic metabolism, or exogenously during ionizing and nonionizing (UV) irradiation, that produces number of radical and peroxide species through the ionization of intracellular water (Cabiscol et al., 2000; Lucana et al., 2012). Reactive by- products of oxygen, such as superoxide anion radical $\left(\mathrm{O}_{2}\right)$, hydrogen peroxide $\left(\mathrm{H}_{2} \mathrm{O}_{2}\right)$, and the highly reactive hydroxyl radicals $(\cdot \mathrm{OH})$, are generated continuously in cells grown aerobically (Cabiscol et al., 2000). These species cause damage to proteins, lipids, and nucleotides, negatively impacting the organism (Lucana $e t$ al., 2012). Therefore, in this study we will examine the antibacterial activity of of Evolvulus nummularius in MDR strains with mechanism of action by estimating the increased percentage of ROS in presence and absence of methanol extract of Evolvulus nummularius.

\section{Materials and Methods}

\section{Preparation plant extract}

Fresh whole plant of Evolvulus nummularius was collected from Suryamaninagar, Tripura. After washing with water this plant materials were allowed to dry in shade. Then whole plants were cut in to small pieces. Then 100 gm of powdered plant materials were soaked in $500 \mathrm{ml}$ of methanol and kept in a shaker for 48 hours. After that the solution was filtered through Whatman filter paper no. 1 for 3 times. Then these solutions were dried in rotary evaporator at $70^{\circ} \mathrm{C}$ (Nicolic et al., 2012). $100 \mathrm{mg}$ of dried extract was dissolved in $1 \mathrm{ml}$ of distilled water and filtered by a 0.22 $\mu \mathrm{m}$ syringe filter and stored at $-20^{\circ} \mathrm{C}$.

\section{Bacterial Culture and growth condition}

MDR Strains klebsiella pneumonia (ATCC BAA-1705), Pseudomonas aeroginosa (ATCC 10145), Enterobacter aerogenes (ATCC 13048) were grown, cultured and maintained on Muller Hinton Broth and stored at $4^{\circ} \mathrm{C}$ (Bhattacharya et al., 2012). For long time storage $15 \%$ glycerol solution was used and vial was stored at $-80^{\circ} \mathrm{C}$.

\section{Bacterial Sensitivity Testing}

All three bacterial strains were cultured on Muller Hinton broth for overnight. Then $2 \mathrm{ml}$ of bacterial cu;lture was poured into the Muller Hinton agar plate, incubated for 5 minutes and excess amount of culture was pipette out from each plate. After that, 8 different antibiotic discs (purchased from HIMEDIA) were kept on respective zone of Muller Hinton agar plate and incubated for overnight at $37^{\circ} \mathrm{C}$.

\section{Determination of Minimum Inhibitory Concentration (MIC)}

MIC was determined by serial dilution technique, with an inoculum of $10^{6} \mathrm{CFU} / \mathrm{ml}$ of both Gram positive and Gram negative bacteria in separate 96 well plate, in presence of increasing concentrations of MEEN. The bacterial cultures were incubated at $37^{\circ} \mathrm{C}$ and shaken at $200 \mathrm{rpm}$ for 24 hours. Then the bacterial cell viability was determined by measuring the OD value at $600 \mathrm{~nm}$. Here, MEEN with media, used as blank; media MEEN and bacterial culture, used as experiment; media with bacterial culture and distilled water, used as positive control; and 
media with only distilled water, used as negative control (Demetrio et al., 2015). Then, $\%$ of Inhibition was calculated by following formula,

$\%$ of Inhibition $=[1-\{($ Exp. - Blank $) /$ (Positive Control - Negative Control) $\}^{*}$ 100]

\section{Determination of Minimum Bactericidal Concentration (MBC)}

After determining the MIC values, MBCs for each bacterial strains were determined by treating the bacteria with 3 different doses, $\mathrm{IC}_{50}, \mathrm{IC}_{100}$ and $>\mathrm{IC}_{100}$ dose. After incubation with these 3 doses, one loop full bacterial culture from each tube was streaked on Muller Hinton agar plate in respective zone and again these plates were incubated at $37^{\circ} \mathrm{C}$ for overnight. $\mathrm{IC}_{100}$ value indicates the concentration which inhibits $100 \%$ of bacterial growth, whereas, MBC value indicates the concentration at which a drug can kill the bacterial species (Demetrio et al., 2015).

\section{Growth Kinetics Studies}

To determine the bacterial growth kinetics, in presence of MEEN, each bacterial species were grown in Muller Hinton Broth in presence and absence of MEEN separately, at $37^{\circ} \mathrm{C}$ at $200 \mathrm{rpm}$ for 12 hours. Here, bacterial cells were treated with respective $\mathrm{IC}_{50}$ dose. Then, the bacterial concentration in presence and absence of MEEN were determined by measuring the OD at $600 \mathrm{~nm}$ in every 1 hour interval. Bacterial growth kinetics was plotted graphically with time versus $\mathrm{OD}_{600}$ (Bhattacharya et al., 2012).

\section{Estimation of Reactive Oxygen Species (ROS)}

$0.1 \mathrm{ml}$ of each bacterial suspension (where $\mathrm{OD}_{600}=1.0$ ) in Hank's balanced salt solution (HBSS) was incubated with respective $\mathrm{IC}_{50}$ dose of MEEN for 3 hours with $15 \mathrm{~min}$ interval at $37^{\circ} \mathrm{C}$. Then $500 \mu \mathrm{l}$ of $1 \mathrm{mg} / \mathrm{ml}$ NBT was added and again incubated for 30 $\min$ at $37^{\circ} \mathrm{C}$. After incubation, $0.1(\mathrm{M}) \mathrm{HCl}$ was added and tubes were centrifuged at $3000 \mathrm{rpm}$ for $10 \mathrm{~min}$. The pellets were treated with $0.6 \mu \mathrm{l}$ of DMSO to extract the reduced NBT. Then, $0.5 \mu$ of HBSS was added and OD was measured at $575 \mathrm{~nm}$ (intracellular ROS) (Pramanik et al., 2012).

\section{Statistical Analysis}

We repeated these experiments for 3 times and data were expressed by calculating the standard deviation of all 3 experiments. ANOVA single factor (using Microsoft Office Excel) was used to determine statistical significance for multiple comparisons. $P<0.05$ was accepted as statistically significant.

\section{Results and Discussion}

\section{Bacterial sensitivity testing}

The sensitivity these 3 bacterial strains were evaluated by using 8 different antibiotic discs. All these strains were resistant to more than 3 antibiotics. As shown in Fig 1 and Table $1 P$. aerugens was resistant to ampicillin, tetracycline and penicillin-G, whereas, E. aerogenes and $K$. pneumoniae were resistant to ampicillin, ciprofloxacin, chloramphenicol, rifampicin and penicillinG. Therefore, these three bacterial strains are multidrug resistant strains.

\section{Determination of Minimum Inhibitory Concentration (MIC)}

Antibacterial activity of MEEN against MDR strains were obtained by determining the minimum inhibitory concentrations. As shown in table 1 and Fig 1, the growth of $E$. aerogenes was inhibited completely at lower 
concentrations of MEEN (2.5 $\mathrm{mg} / \mathrm{ml})$, but growth of $K$. pneumoniae were completely inhibited at too higher concentration of MEEN (10 mg/ml). The order of observed sensitivity on 3 different bacterial strains were, E. aerogenes $>P$. aeruginosa $>K$. pneumoniae.

\section{Determination of $\mathrm{MBC}$}

Minimum bactericidal concentration of MEEN on each bacterial strain was also determined, shown in Fig. 2A and 2B. Table 2 and 3 showed that, the ratio between MBC and MIC for each bacterium is same $(\sim 1$, for all bacteria). This result indicated that, MEEN is a bactericidal agent. It not only inhibits the bacterial growth but also can kill multi drug resistant bacterial strains.

\section{Bacterial Growth Kinetics Studies}

We next measured the growth curve of both gram negative and gram positive bacterial strains to examine whether MEEN has any effect on growth pattern of each bacterium. All three bacterial strains were exposed to MEEN separately, at a concentration of $\mathrm{IC}_{50}$ dose for each bacterium. As shown in Fig 3A and $3 \mathrm{~B}$, the lag phase of all MEEN treated bacteria were extended compared to control. Among all these bacteria, the growth curve of $E$. aerogenes is mostly affected by MEEN.

Table.1 Effect of different antibiotics on gram negative multidrug resistant bacterial strains.

This data is significant at a level of $\mathrm{p}<0.05$

\begin{tabular}{|l|c|c|c|}
\hline \multicolumn{1}{|c|}{ Bacteria } & K. pneumoniae & P. aeruginosa & E. aerogenes \\
Antibiotics & & & \\
\hline Streptomycin & + & + & + \\
\hline Ampicillin & - & - & - \\
\hline Tetracyclin & + & - & - \\
\hline Chloramphenicol & - & + & - \\
\hline Rifampicin & - & + & + \\
\hline Gentamycin & + & + & - \\
\hline Coprofloxacin & - & + & - \\
\hline Penicillin G & - & - & \\
\hline
\end{tabular}

"+" = Sensitive; "

Table.2 MIC values for gram negative MDR bacterial strains.

This data is significant at a level of $\mathrm{p}<0.05$.

\begin{tabular}{|l|c|c|}
\hline Bacteria & $\mathbf{I C}_{\mathbf{5 0}}(\mathbf{m g} / \mathbf{m l})$ & $\mathbf{I C}_{\mathbf{1 0 0}}(\mathbf{m g} / \mathbf{m l})$ \\
\hline K. pneumoniae & $5 \pm 0.38$ & $10 \pm 0.45$ \\
\hline $\boldsymbol{P}$. aeruginosa & $2.5 \pm 0.17$ & $5 \pm 0.34$ \\
\hline E. aerogenes & $1.25 \pm 0.32$ & $2.5 \pm 0.32$ \\
\hline
\end{tabular}


Table.3 MBC values for gram negative bacterial species

\begin{tabular}{|l|c|c|}
\hline Gram (-) Bacteria & MBC & IC $_{\mathbf{1 0 0}} / \mathbf{M B C}$ \\
\hline K. pneumonia & $10 \mathrm{mg} / \mathrm{ml}$ & 1 \\
\hline P. aeruginosa & $5 \mathrm{mg} / \mathrm{ml}$ & 1 \\
\hline E. aerogenes & $2.5 \mathrm{mg} / \mathrm{ml}$ & 1 \\
\hline
\end{tabular}

Fig 1 Muller Hinton Agar Plate showing antibiotic sensitivity of Gram negative Bacteria (A, B)

$K$. pneumoniae, (C, D) P. aeruginosa, (E) E. aerogenes
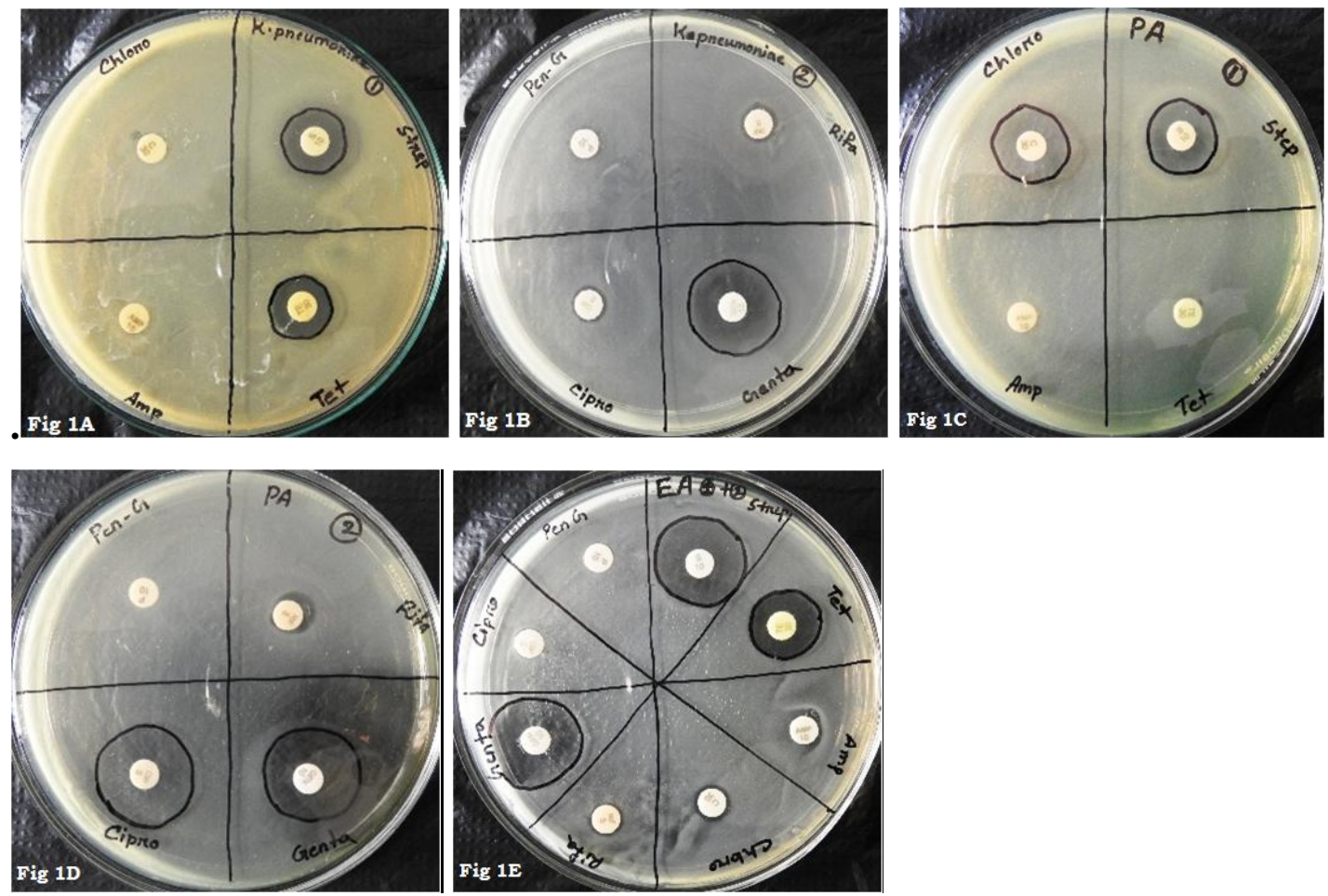

Fig 2 Column diagram IC100 dose of MEEN

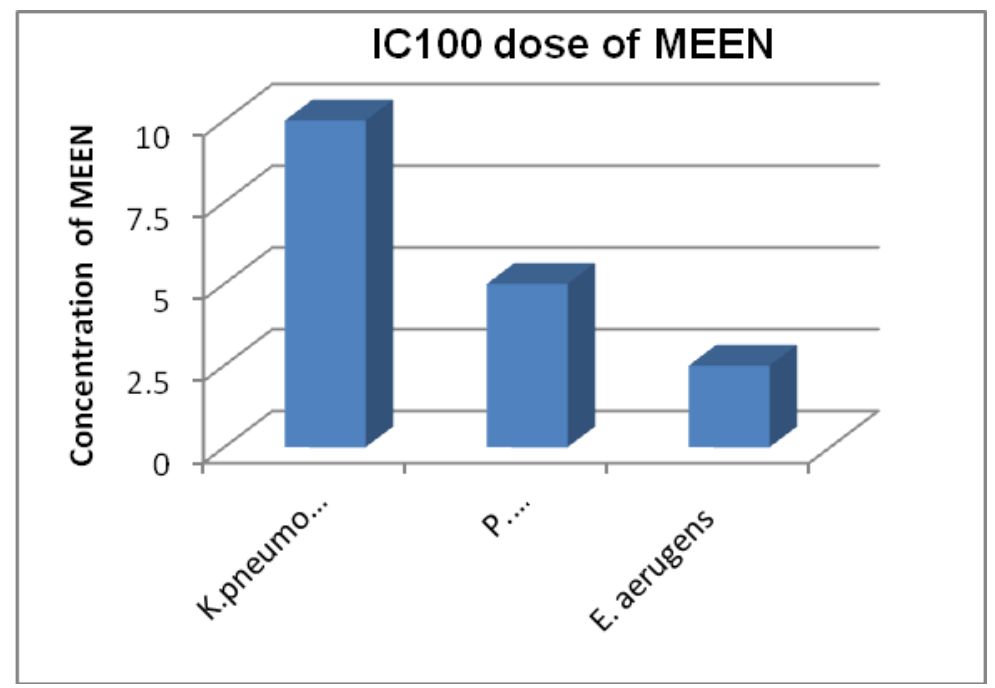


Fig 3 Muller Hinton Agar Plate showing MBC of Gram negative Bacteria (A) K. pneumoniae, (B) P. aeruginosa, (C) E. aerogenes

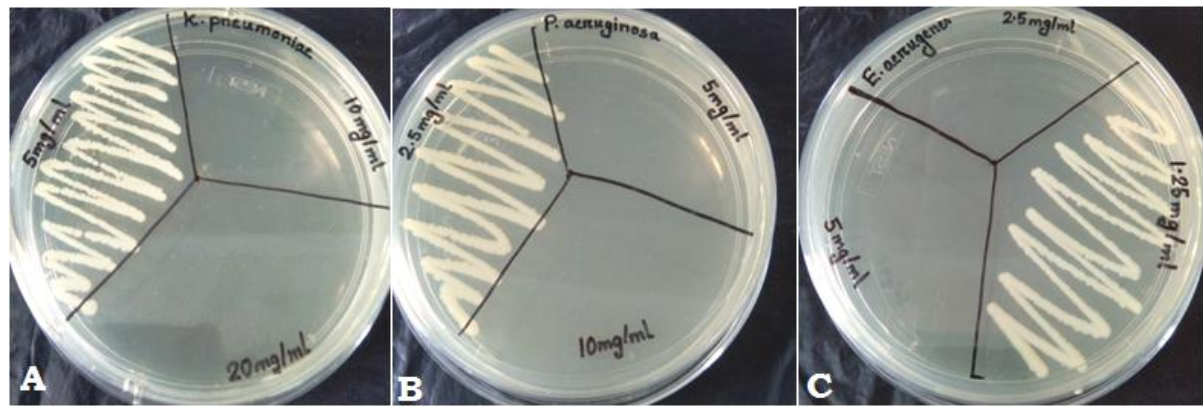

Fig 4 Growth curve of MDR strains in presence and absence of MEEN. This data is significant at a level of $\mathrm{p}<0.05$

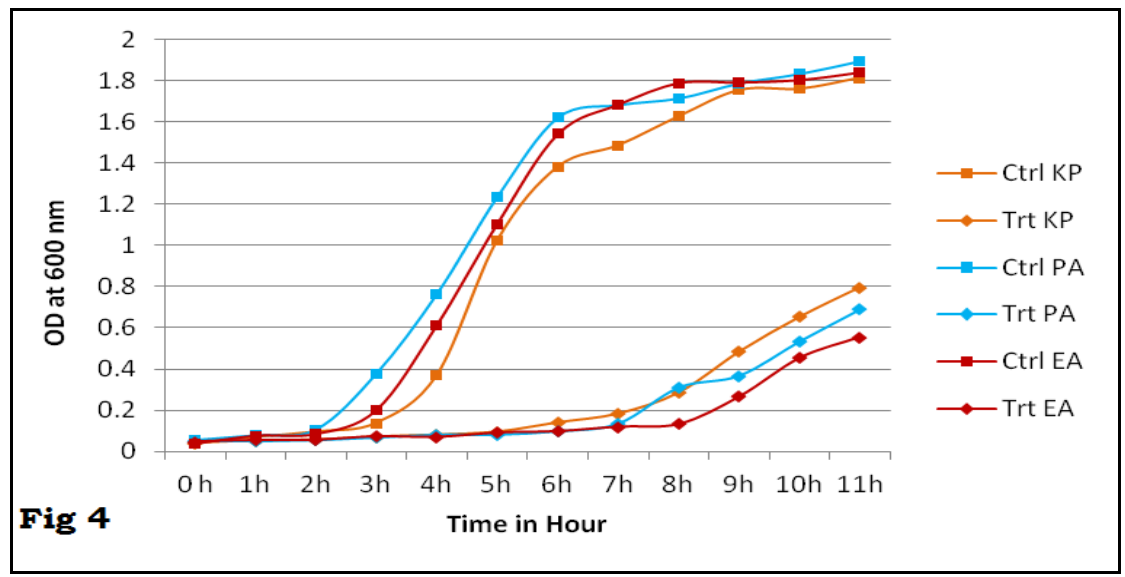

Fig 5 Normalized \% of ROS produced by gram negative MDR bacterial strains in presence of MEEN. This data is significant at a level of $\mathrm{p}<0.05$

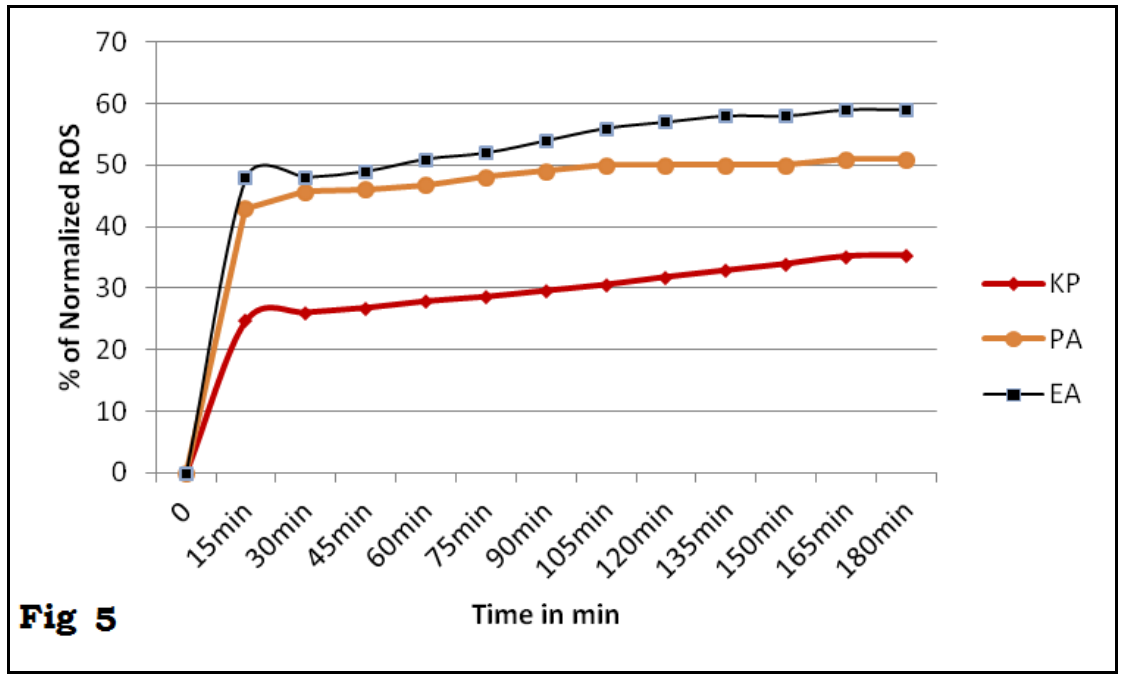




\section{Estimation of ROS}

Finally, to understand the mechanism of antibacterial activity of MEEN, intracellular reactive oxygen species (ROS) was estimated after treatment with MEEN at $\mathrm{IC}_{50}$ dose.

As shown in Fig 4A and 4B, after treatment of MEEN, the production of ROS was increased drastically with time. It was highest in E. aerogenes, in which ROS production increased about $60 \%$ in 3 hours compared to control. The order of observed ROS production on 3 MDR strains were, $E$. aerogenes $>P$. aeruginosa $>K$. pneumoniae.

In present study the effect of Evolvulus nummularius on generation of ROS in MDR strains were evaluated to explore the mode of action of antibacterial activities of this plant. The growth of gram negative multidrug resistant bacterial strains were inhibited completely at lower concentrations of MEEN (2.5 $-10 \mathrm{mg} / \mathrm{ml})$. The $\mathrm{IC}_{100}$ dose of MEEN for $E$. aerogenes, $P$. aeruginosa and $K$. pneumoniae were $2.5 \mathrm{mg} / \mathrm{ml}, 5 \mathrm{mg} / \mathrm{ml}$ and $10 \mathrm{mg} / \mathrm{ml}$ respectively. Minimum bactericidal concentration (MBC) of MEEN on each bacterial strain was also determined. The result showed that, the ratio between $\mathrm{MBC}$ and MIC for each bacterium is same $(\sim 1$, for all bacteria). Therefore, MEEN showed both bacteriostatic and bactericidal activity against multidrug resistant strains of bacteria.

For growth kinetics studies, all the bacterial strains were exposed to MEEN separately, at a concentration of $\mathrm{IC}_{50}$ dose for each bacterium and the lag phase of all MEEN treated bacteria were extended compared to control. Among all these bacteria, the growth curve of E. aerogenes is mostly affected by MEEN.

Finally, to understand the mechanism of antibacterial activity of MEEN, intracellular reactive oxygen species (ROS) was estimated after treatment with MEEN at $\mathrm{IC}_{50}$ dose. After treatment of MEEN, the production of ROS was increased drastically with time. It was highest in E. aerogenes, in which ROS production increased about $60 \%$ in 3 hours compared to control. The range of increased ROS production in MDR strains was about $35 \%$ to $60 \%$. This was the sufficient concentration to kill the bacterial strains.

Therefore, the crude methanol extract of Evolvulus nummularius may be used as a potent source of antibacterial agent because, MEEN was effective against MDR strains, which are resistant to commercially available antibacterial agents.

\section{References}

Al-Bari, M.A.A., Hossen, M.F., Khan, A., Islam, M.R., Kudrat- E- Zaha, M., Mosaddik, M.A., Zakarja, C.M., Islam, M.A.U. 2007. In-vitro antimicrobial and cytotoxic activities of Ferrocene derivative compounds. Pak. J. Biol. Sci. 10 (15): 2423-2429.

Bhattacharya, D., Samanta, S., Mukherjee, A., Santra, C.R., Ghosh, A.N., Niyogi, S. K. and Karmakar, P. 2012. Antibacterial Activities of Polyethylene Glycol, Tween 80 and Sodium Dodecyl Sulphate Coated Silver Nanoparticles in Normal and Multi-Drug Resistant Bacteria. J. NanoSci. Nano Tech., 12: 1-9.

Cabiscol, E., Tamarit, J., Ros, J. 2000. Oxidative stress in bacteria and protein damage by reactive oxygen species. Int. Microbiol., 3: 38.

Chitralekha, C., Dey, P. K., Dey, C.D. 1964. Pharmacological screening, of Valeriana wallichii, Lallemantia royleana, Breynia rhamnoides and Evolvulus nummularius for sedative 
and anti-convulsant principles. Naturwis senschaften, 51: 411.

Das, H.B., Majumdar, K., Datta, B.K., Roy, D. 2009. Ethnobotanical uses of some plants by Tripuri and Reang tribes of Tripura. Natural Product Radiance, 8(2): 172- 180.

Dash, G.K., Bijayini, M., Panda, A., Patro, C. P., Ganapaty, S. 2003. Antihelmintic activity of Evolvulus nummularius. Indian J. Nat. Prod., 19: 24-6.

de Oru'e Lucana, D.O., Wedderhoff, I., Groves, M.R. 2012. ROS-mediated signalling in bacteria: zinc- containing cys- $\mathrm{X}-\mathrm{X}$-cys redox centres and ironbased oxidative stress. J. Sig. Trans., 9. doi:10.1155/2012/605905.

Deb, D.B. 1983. The flora of Tripura state. Today \& Tomorrow's Printers and Publishers. New Delhi Vol. 2: 254255.

Demetrio, L.V.J., Jeannie, I.A., Juliana, J.M. P, Esperanza, C.C., Windell, L.R. 2015. Antibacterial activities of ethanol extracts of Philippine medicinal plants against multidrug-resistant bacteria. Asian Pac. J. Trop. Biomed., 5(7): 532540.

Dinda, B., Ghose, B., Shiho, A., Nariko, S., Yoshihiro, F. 2007. Chemical Constituents of Evolvulus nummularius. Indian J Chem., 46: 49298.

Nikolic, M., Vasic, S., Durđevic, J., Stefanovic, O. and Comic, L. 2014.
Antibacterial and anti-biofilm activity of ginger (Zingiber officinale (roscoe)) ethanolic extract. Kragujevac J. Sci. 36: 129-136.

Pramanik, A., Laha, D., Bhattacharya, D., Pramanik, P., Karmakar, P. 2012. A novel study of antibacterial activity of copper iodide nanoparticle mediated by DNA and membrane damage. Colloids and Surfaces B: Biointerfaces, 96: 5055.

Rojas, J.J., Ochoa, V.J., Ocampo, S.A., Munoz, J.F. 2006. Screening for antimicrobial activity of ten medicinal plants used in Colombian folkloric medicine: A possible alternative in the treatment of non-nosocomial infections. BMC Complement Altern. Med., 6:2.

Roy, M., Chakama, B., Datta, B.K., Gupta, A.K. 2010. Traditional knowledge of medicinal plants used by Chakma tribal community of Tripura, India. Pleione, East Himalayan Society for Spermatophyte. Taxonomy, 4(1): 105112.

Saini, V., Kinger, H.K., Sharma, D.K., Ahuja, N., Middha, A., Gupta, V.B. 2007. Wound healing activity of Evolvulus numularius Linn. Asian J. Chem., 19: 5772- 5774.

Zy, E.A., Area, A., Aam, K. 2005. Antimicrobial activity of some medicinal plant extracts in Palestine. Pak. J. Med. Sci. 21: 187-193.

\section{How to cite this article:}

Susmita Saha, Anindya Das, Angkita Debnath, Shipa Begam, Subrata Sen, Swapan Majumdar and Samir Kumar Sil. 2017. Increased ROS Generation: Implication in Antibacterial Activity of Evolvulus nummularius against Multidrug Resistant Gram Negative Bacterial Strains. Int.J.Curr.Microbiol.App.Sci. 6(1): 100-107. doi: http://dx.doi.org/10.20546/ijcmas.2017.601.013 